\title{
Management of IT Outsourcing in the Slovenian Public Sector - Material and Procedural Aspects
}

UDK: 35:004(497.4)

Dalibor Stanimirović

University of Ljubljana, Faculty of Administration, Institute for Informatization of Administration

dalibor.stanimirovic@fu.uni-li.si

Mirko Vintar

University of Ljubljana, Faculty of Administration, Institute for Informatization of Administration

mirko.vintar@fu.uni-li.si

\section{ABSTRACT}

Public sector management in Slovenia has been following the trends in information technology (IT) outsourcing since the mid-nineties of the last century. Being aware of the complex role of IT in modern public sector organizations and its ubiquitous implications, the paper focuses on in-depth analysis of the critical success factors, benefits and risks within the concept of IT outsourcing, while employing the international studies and primarily the results of own research examining the current situation and identifying the main drivers for IT outsourcing in Slovenian municipalities. The paper additionally analyses the material, procedural and other relevant aspects within the process of IT outsourcing, provides an overview of its potentially positive and negative implications and eventually presents a contextual framework for management of IT outsourcing along with applicable guidelines for effective utilization and implementation of IT outsourcing in the public sector.

Key words: IT outsourcing, public sector, municipal IT outsourcing, IT outsourcing process, framework for management of IT outsourcing

JEL: H72, M15

Stanimirović, D. \& Vintar, M. (2012). Management of IT Outsourcing in the Slovenian Public Sector - Material and Procedural Aspects. 


\section{Introduction}

Confronted with rapid technological developments in the mid-nineties of the last century, Slovenian public sector organizations have adopted the utilization of IT outsourcing as one of the viable solutions to deal with the intractable and costly IT-sourcing issues. IT outsourcing was expected to generate savings of public sector organizations in the process of developing IT infrastructure and information systems (IS), providing modern IT service for citizens and public officials and facilitating better quality information resources management in the public sector (Kakabadse \& Kakabadse, 2001; Kim et al., 2007; Lacity et al., 2010). Past experience and recent research carried out in the public sector show that IT outsourcing can indisputably bring many benefits to the organizations which master the art of devising, deploying, and maintaining outsourcing relationships (Linder, 2004; Corbett, 2004; Ghodeswar \& Vaidyanathan, 2008), however many organizations find those benefits elusive, while outsourcing projects are usually accompanied by unexpected and often negative effects (Chapman \& Andrade, 1997; Kern et al., 2002; Taylor, 2006; Cordella \& Willcocks, 2010). Slovenian public sector has encountered problems with IT outsourcing especially in the last five years, while the on-going financial and economic crisis and the subsequent austerity measures just revealed their magnitude (Stanimirović, 2010), indicating that IT outsourcing cannot provide a workable long-term solution in every IT-related project.

The main goal of the paper is to examine the state of IT outsourcing in Slovenian public sector and highlight its material and procedural aspects. The identification and systemization of the phenomenon ought to enable easier and more effective management of IT outsourcing in the future. Referring predominantly to own research and given the theoretical foundations of foreign and domestic authors, the paper is focusing primarily on the following research questions:

1. Overview of the current situation in the field of IT outsourcing and identification of the main drivers for IT outsourcing in Slovenian municipalities.

2. Analysis and characterization of the key material and procedural factors applicable in planning and implementation process of IT outsourcing at the municipal level. 
3. Construction of contextual framework for quality management of IT outsourcing and presentation of applicable guidelines for effective utilization and implementation of IT outsourcing in the public sector.

Following the introduction of main research questions, the first section of the paper presents the outsourcing concept and an overview over the relevant literature while outlining contextual considerations and implications of sourcing alternatives. The second section reveals the characteristics of own survey examining IT outsourcing in Slovenian municipalities, its results and their synthesis, providing an insight of the main drivers for IT outsourcing at the municipal level. The third section presents the contextual framework for quality management of IT outsourcing based on the material and procedural factors, obtained from the conducted survey, while the last section contains the evaluation of the presented approach, discussion on its practical applicability and description of its positive features and limitations, and subsequently submits the final arguments and observations regarding the IT outsourcing phenomenon.

\subsection{IT outsourcing concept and its implications}

Ellram and Maltz (1997) argue that outsourcing is a contractual transfer of organizational activities and responsibilities to other (external) business entity. They emphasize that the volume of outsourced activities depends on their content and the needs of the parent organization. Kubr (2002) defines outsourcing as a contractual elimination and transfer of the activity, for which the organization decides not to perform it itself in future, to the external business entities. Such an operating strategy in his view, allows the efficient allocation of resources. Literature presents a wide range of different definitions, ranging from the most consistent and accurate up to superficial and partial definition of the phenomenon, while the most useful and versatile is its most widespread and widely accepted definition, which reads as follows: "Outsourcing is a contractual transfer of certain activities and business processes from the parent organization to the external contractor« (Greaver, 1999).

Outsourcing is a business strategy of transferring the selected organization's activities to the external supplier in order to improve business performance (Florin et al, 2005; Ghodeswar \& Vaidyanathan, 2008) and primarily cut back costs (Kim, 2003) as well as focus on its 
core functions (Power et al., 2006), which should consequently improve service provision and quality (Corbett, 2004). It is one of the main components of New Public Management (NPM) paradigm used by governments in their efforts to modernise public sector (Hodgson et al., 2007) and make it more market-oriented as well as cost efficient (Hood \& Peters, 2004). Public sector reforms have been driven both by budgetary pressures requiring reduced government spending (Martin, 2010) and by the influence of economic theories (Lapsley, 2009) about public administration and its function. Several studies of outsourcing (Florin et al., 2005; Kim, 2003; Corbett, 2004; Linder, 2004; Ghodeswar \& Vaidyanathan, 2008; Ho \& Atkins, 2010) report considerable positive effects, savings and increased efficiency; in general they outline positive impacts of outsourcing while others find no benefit or even increased costs resulting from tendering and contracting out (Taylor, 2006; Kakabadse \& Kakabadse, 2001; Chen \& Bharadwaj, 2009; Cordella \& Willcocks, 2010).

Diverse studies (Lonsdale \& Cox, 1997; Linder, 2004; Nellore \& Soderquist, 2000; Wadhwa \& Ravindran, 2007) as well as own research of IT outsourcing in Slovenian public sector conducted in 2010 by the Institute for Informatization of Administration (Stanimirović, 2010), revealed positive implications of outsourcing which are divided into four categories and presented in Table 1.

Despite positive implications listed in Table 1, rationalization of the public sector using IT outsourcing experienced particular problems as well, the significance of which has been revealed only after a certain period of time. While lacking experience as well as formal regulations and expertise in the field of IT outsourcing, public sector started straying to the growing and increasingly less justified IT outsourcing ventures, leading to a completely opposite effect than expected and desired. Reported expenditures on IT outsourcing in Slovenian public sector have doubled in last years and in the deteriorating fiscal situation reach tens of millions of Euros (Stanimirović, 2010). Besides eligible decisions to outsource noncore processes and functions (software development and prototyping, website designing, maintenance of IT infrastructure in relation to computer hardware and software, integration of IT systems, networks and security, training and education etc.) public sector organizations resorted to outsourcing of core business activities essential in providing public benefits and overall development of public sector (development and 
implementation of major strategic IT projects - e-government, e-health, customer help desk regarding administrative issues, IT consulting and preparation of feasibility studies, development strategies and action plans, preparation and implementation of public tenders for IT projects, drafting of legislative proposals regarding the role of IT and IT service provision in the public sector etc.). The actions listed have established relative dependence on external IT suppliers causing loss of control over longterm development perspective of IT in the public sector, while the vendor lock-in has eventually resulted in weak control over increasing costs and in reduced accountability for IT projects and services (Stanimirović, 2010).

\section{Table 1: Positive implications of IT outsourcing in the public sector}

\begin{tabular}{l}
\hline Organizational and corporate implications \\
\hline focus on core business and activities; \\
\hline increased business flexibility in changing social conditions; \\
\hline restructuring the organization; \\
\hline creating higher added value products/services, increased customer satisfaction \\
and generating greater returns to capital investments. \\
\hline Increased efficiency implications \\
\hline improving operational efficiency that may result in better quality, greater productivity, \\
shorter investments cycle, increasing returns; \\
\hline access to knowledge, experience and modern technology; \\
\hline improved governance and control processes; \\
\hline minimizing risk when operating in-house; \\
\hline access to innovative ideas and solutions. \\
\hline Financial implications \\
\hline reduced future investment in assets that can be provided by external supplier; \\
\hline focus on in-house investments; \\
\hline increased market share and exploitation of business opportunities offered by a \\
network of partner organizations; \\
\hline faster growth of the organization possibility of using the partner's capabilities, \\
processes and systems. \\
\hline Cost implications \\
\hline reduced costs due to the external supplier's performance and price of products or \\
services; \\
\hline transformation of fixed costs into variable costs; \\
\hline decreased costs due to the large reductions in the value of fixed assets. \\
\hline
\end{tabular}

Considering the above assumptions and international studies (Bongard, 1994; Chapman \& Andrade, 1997; Greaver, 1999; Power et al., 2006; 
Jensen, 2007) and predominantly the results of own research mentioned earlier (Stanimirović, 2010), the potential negative implications and effects of IT outsourcing are highlighted as they follow (Table 2).

Table 2: Negative implications of IT outsourcing in the public sector

\begin{tabular}{l}
\hline Organizational performance implications \\
\hline reduced quality of services; \\
\hline user related problems (technical support, service information, user satisfaction etc.); \\
\hline reduced accountability for services. \\
\hline Human resources implications \\
\hline loss of core competencies; \\
\hline dissatisfaction and insecurity; \\
\hline unstimulating working environment; \\
\hline "brain drain". \\
\hline Organizational risk implications \\
\hline loss of control over the most important organizational functions; \\
\hline loss of control over preparation, development and realization of planned projects; \\
\hline complete dependence on external contractor; \\
\hline collusive tendering and other tendering problems. \\
\hline Cost implications \\
\hline loss of control over increasing costs; \\
\hline hidden costs; \\
\hline unexpected costs. \\
\hline
\end{tabular}

The continuation of this paper presents up to date literature and research concerning the outsourcing phenomenon, which have been trying to resolve the problems addressed above and facilitate better quality management as well as more objective and comprehensive controlling of outsourcing projects.

\subsection{Literature review and recent research}

The first systematic and scientific research of outsourcing can be found in the late eighties and early nineties of the last century (Ford \& Farmer, 1986; Due, 1992; Willcocks \& Lacity, 1995 etc.). Thorough scientific studies of the impact and importance of outsourcing are still rare. Authors are most often focusing on a rather narrow perspective, usually costs and other particularly financial benefits, but do not provide sufficiently comprehensive answers neither regarding the long-term implications 
of outsourcing nor the management of outsourcing in the public sector based on objective material and procedural aspects. Here it should be noted that private sector has been adopting a portfolio approach to ITrelated sourcing decisions (Hirschheim \& Lacity, 2000) in the last period, while this trend is gradually transferring to the public sector as well (Scholl, 2006). IT portfolio approach represents a comprehensive strategy for management of IT infrastructure, provision of IT services, IT development and all IT-related operations within the organization, it should enable public sector organizations to systematically align IT investments and harmonize IT sourcing decisions with business objectives and provide IT support to all business functions in maximizing public benefits, while maintaining a constant focus on customers and costs (Bongard, 1994; Hirschheim \& Lacity, 2000; Scholl, 2006). Contrary to the generally accepted view that IT outsourcing means lower costs and greater flexibility, convincing empirical evidence regarding the benefits of IT outsourcing in the public sector is not sufficiently elaborated, particularly when considering long-term aspects of IT outsourcing (Boyne, 1998; Kakabadse \& Kakabadse, 2001; Lacity et al., 2010; Kim et al., 2007; Cordella \& Willcocks, 2010). Nevertheless, because of its complexity, pervasiveness and broad implications, the number of outsourcing researchers has been rising in recent years. Experts in this area (Corbett, 2004; Jensen, 2007) claim that the phenomenon of outsourcing gained so much importance over the last twenty years due to the global social change and transformation as well as the booming public sectors worldwide.

Previous research of outsourcing (Quinn \& Hilmer, 1994; Johnson, 1997; Lonsdale \& Cox, 1997; Linder, 2004; Jacobides, 2005) is largely exploring the financial implications of outsourcing and mainly presents parent organizations dissatisfaction with the on-going projects which are often terminated before expected (Ravindran et al., 2009; Kavčič \& Tavčar, 2008). Despite growing interest in the phenomenon of outsourcing, which has recently raised increasing attention among researchers in the fastest growing economies over the past few years, namely the authors in India (Pandey \& Bansal, 2003; Wadhwa \& Ravindran, 2007) and China (Lee et al., 2002; Kim, 2003; Choy et al., 2005), it is difficult to trace a comprehensive management strategy for preventing or resolving problems of outsourcing projects. Studies (Kern et al., 2002; Schniederjans et al., 2005; Taylor, 2006) often reveal the 
hidden costs as the most problematic segment of outsourcing, in which problems usually occur when organizations are already heavily involved in the outsourcing projects and the termination of contract in that phase would inflict large financial losses for both sides. Surprisingly, research is rarely dealing with the other negative consequences that may pose a potential threat.

On the other hand, outsourcing literature (Barney 1991; Peteraf, 1993; Nellore \& Soderquist, 2000) deals with separate aspects of the parent organization and the external contractor and rarely addresses the outsourcing projects in an integrated manner in which attention is focused to the whole project, rather than individual business entities within the project (Kavčič \& Tavčar, 2008). Accordingly, most sourcing-related studies in e-government, if any, focus on outsourcing and not on the sourcing subject as a whole (Scholl, 2006). Here it should be noted that the material and procedural criteria presented by the most literature, which should form the basis for quality management of outsourcing, are extremely vague and arbitrary and consequently prevent organizations to implement a long-term successful outsourcing project. Existing research (Kern et al., 2002; Linder, 2004; Power et al., 2006) is mainly focused on a small number of criteria, which consider only short-term and partial aspects of business cooperation between the parent organization and the external contractor and do not address long-term, strategic implications of outsourcing projects. IT investments are often juxtaposed to other investments in fixed assets, while in fact they are poles apart, as they represent the basic strategic element of information resources management and define the main trajectory of public sector organizations development and their action in the future (Rocheleau \& Wu, 2002).

Considering the nature and characteristics of IT outsourcing, a multidisciplinary method which includes structured and balanced approach in addressing the overall problem, is essential. While listed research and studies represent a firm foundation for better understanding of the outsourcing problem, their main drawback is evaluation of IT outsourcing from rather narrow and static aspects while ignoring its broad organizational and social implications and other issues specific only to the public sector studied in this paper. Contextual framework for management of IT outsourcing in the public sector presented in this paper exceeds the limitations of existing research, since it is considering the implications of IT outsourcing on different organizational aspects and conducting analysis of 
IT outsourcing projects in the broader perspective. Presented studies are predominantly unilateral and focused primarily on short-term cost indicators which highlight mainly the financial background of the whole problem. The latter makes it impossible to adopt quality and comprehensive management strategy facilitating long-term effective and efficient governing of IT outsourcing in the public sector.

The conducted research has set a broader research framework, covering all the specifics of the public sector hoping they can provide a starting point for the construction of comprehensive management strategy which could, subject to material and procedural requirements, enhance the efficiency of outsourcing. The method used will help generate effective long-term management strategy and align outsourcing project goals with public sector goals.

\section{Survey of IT outsourcing in Slovenian municipalities}

The survey was conducted during the first six months of 2010 by the Institute for Informatization of Administration at the Faculty of Administration (University of Ljubliana), in a sample of 85 municipalities (211 municipalities in Slovenia, which means that the sample covered $40.28 \%$ of all municipalities). 64 municipalities responded to the survey $175.29 \%$ response rate of the sample, which means that the realized sample amounted to $30.33 \%$ of the total number of municipalities in Slovenia). Directing this survey we focused primarily on the municipalities which are predominantly very small in Slovenia and subsequently the implications of IT outsourcing are much more significant, while IT outsourcing consumes bigger proportion of the annual budget than in larger governmental agencies. The questionnaire consisted of qualitative and quantitative indicators, adjusted for objective and comprehensive ex ante evaluation of the outsourcing projects in public sector organizations.

The purpose of the research is detailed and comprehensive analysis of the situation in the field of IT outsourcing at the municipal level in Slovenia, with special emphasis on the analysis of different organizational factors within public sector domain. Methodology within the survey focuses particularly on the financial, organizational, customer and human resources perspective. The findings obtained will enable the construction of a contextual framework for quality management and implementation of IT outsourcing in the public sector. 


\subsection{Survey results and their synthesis}

Assessing the current situation in the field of IT outsourcing, the survey revealed that as many as 51 (80.00\%) surveyed municipalities believe that IT outsourcing cannot negatively affect the organization and its human resources. The study has also discovered that $64.00 \%$ of the surveyed municipalities are not familiar with potential long-term impacts of IT outsourcing directly related to "hollowing out effect" (loss of core competencies within the organization), and are consequently unaware of potential risks when signing an outsourcing contract. Estimated risks of the IT outsourcing were assessed with an average rating of 3.78 on the scale of 1 to 5 where 1 means high and 5 is negligible (2 fairly large, 3 medium, 4 small). In addition 41 (64.00\%) municipalities have clear definitions of their core business and activities, which should not be outsourced under any circumstances, as well as clear understanding of supporting activities which could be outsourced under certain conditions, while $23(36.00 \%)$ municipalities have no clear position on this issue. 50 (78.00\%) municipalities argue that IT outsourcing facilitates greater cost effectiveness, while 14 (22.00\%) municipalities state the opposite. Overall ratings of municipalities considering their satisfaction with IT outsourcing results and outcomes have reached very high. On the scale from 1 to 5 (1 - dissatisfied and 5 - very satisfied) mean value has reached 4.05 (std. error of mean 0.96 and std. deviation 0.76) (Graph 1).

\section{Graph 1: Satisfaction with the results and outcomes of IT outsourcing}

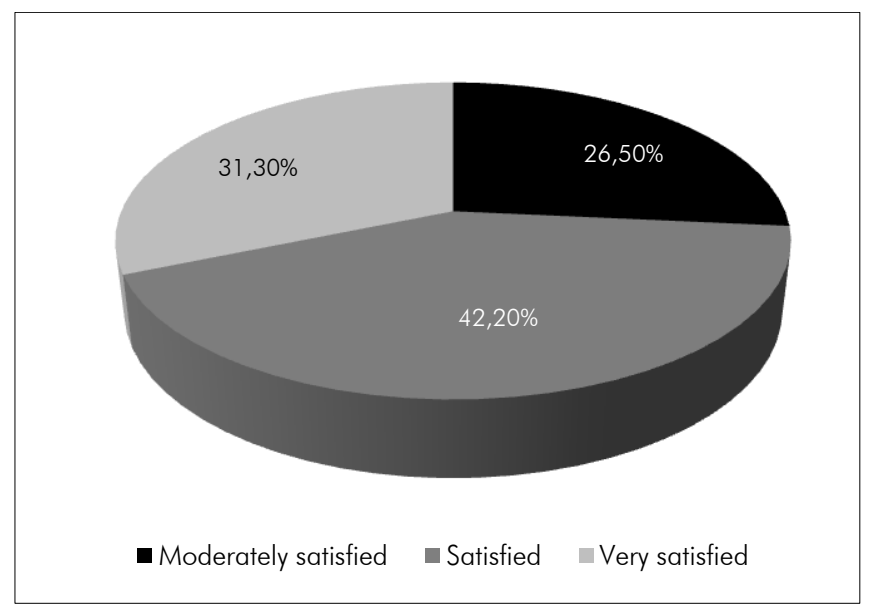


Regarding the vendor lock-in issue and focusing on different pressures in the selection of external suppliers, $5(8.00 \%)$ municipalities stated they have undergone various forms of pressures, $41(64.00 \%)$ municipalities have not detected any pressure, while 18 (28.00\%) surveyed municipalities are not acquainted with these pressures.

Considering material and procedural factors applicable in planning and implementation process of IT outsourcing, results revealed that the municipalities do not use formal methodologies. Their planning activities are focused largely on financial aspect of IT outsourcing. Accordingly, 30 (46.90\%) municipalities underlined financial reasons as the main argument for IT outsourcing, while 14 (21.80\%) municipalities pointed out improvement in customer relations and satisfaction as the main argument, $12(18.80 \%)$ municipalities emphasized the enhancement of internal business processes and 8 (12.50\%) municipalities accentuated the advancements in the field of learning and growth as the main argument for IT outsourcing (Graph 2).

\section{Graph 2: Reasons for IT outsourcing in Slovenian municipalities}

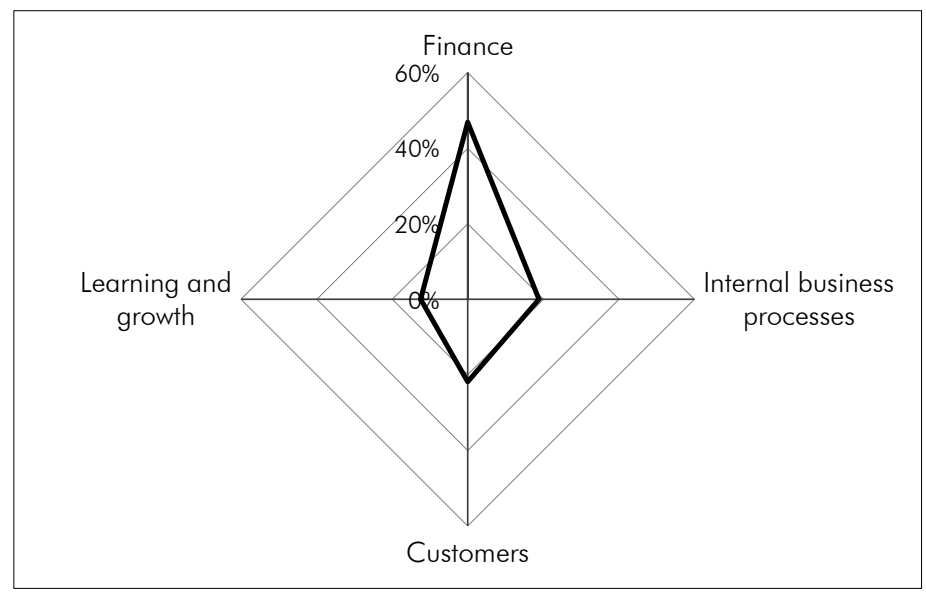

In compliance with the above findings we can see the main drivers for IT outsourcing, identified in Slovenian municipalities and itemized below, extend to different areas (Graph 3). Graph 3 displays the number and percentage of municipalities opted for a particular driver. Assessing the main drivers for IT outsourcing in respondent municipalities on a scale of 1 to 5 , where 1 is unimportant and 5 is very important (2 fairly important, 
3 medium-important, 4 important), the survey revealed the values presented in Graph 4.

\section{Graph 3: Main drivers for IT outsourcing in Slovenian municipalities}

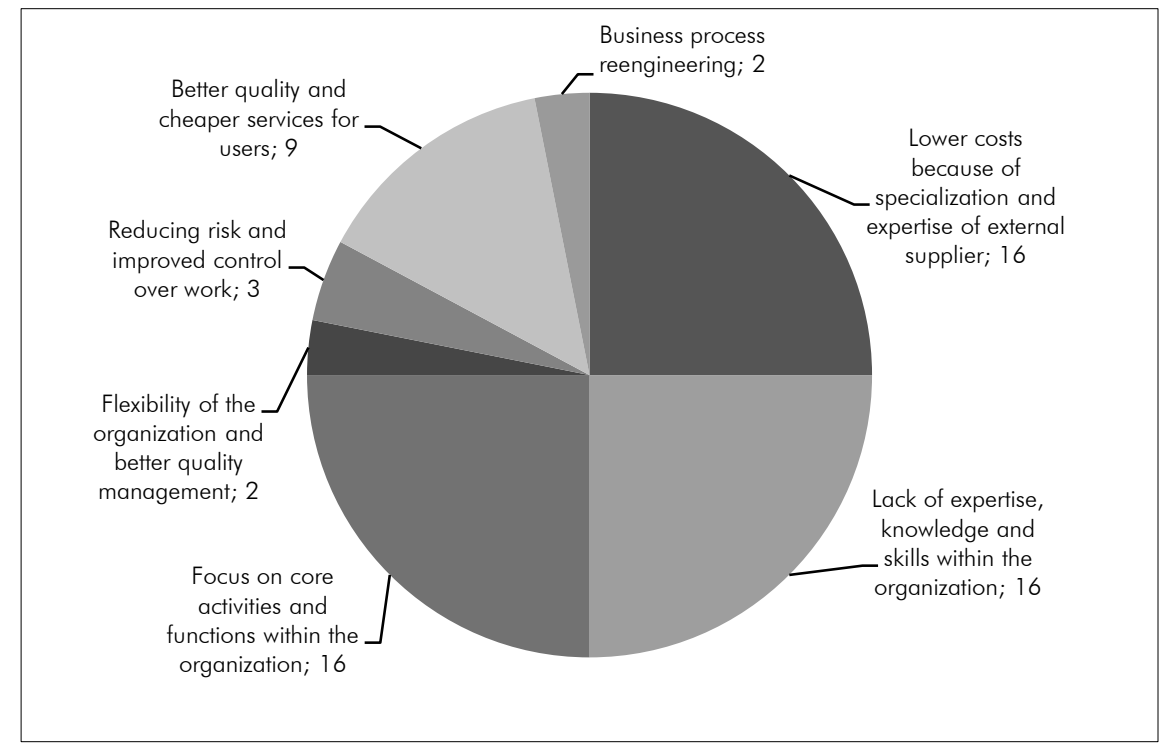

\section{Graph 4: Assessing the value of main drivers for IT outsourcing}

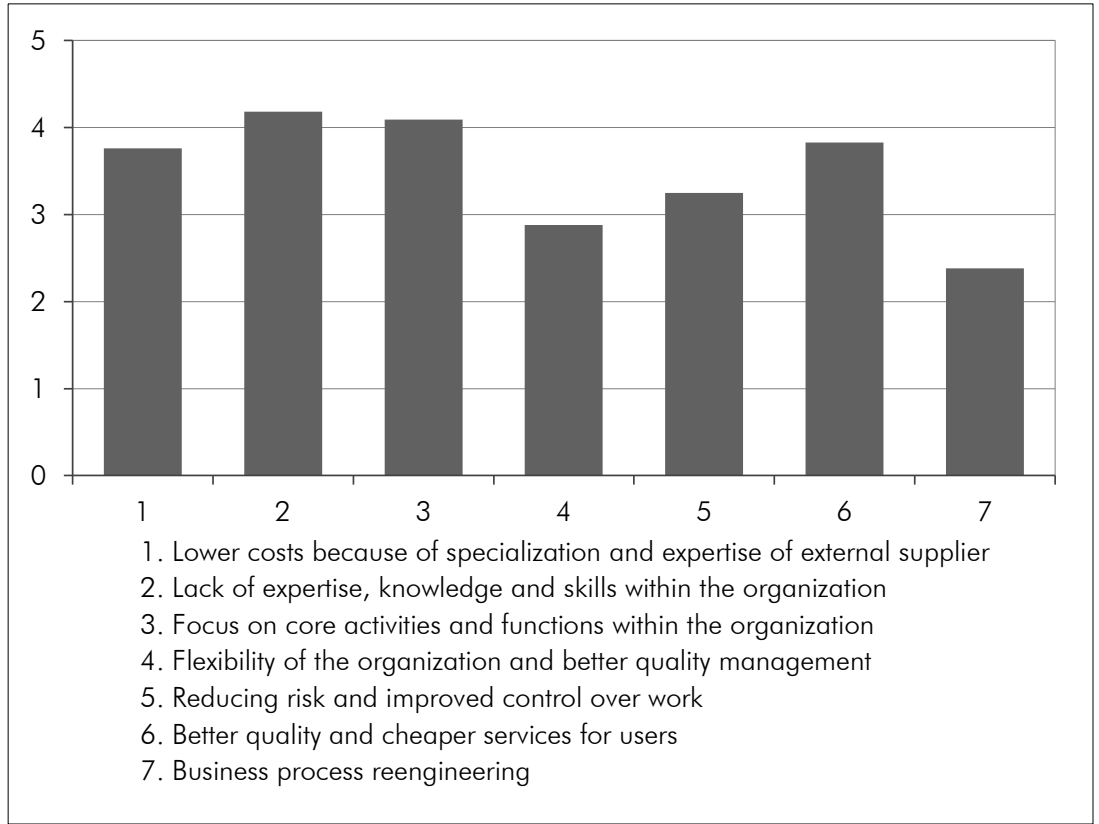


On the other hand, municipalities have highlighted the potential negative implications of IT outsourcing as well, namely the survey results have indicated that $37(57.82 \%)$ municipalities believe that financial aspect is most exposed to potential negative impacts of IT outsourcing in the long run, 10 (15.63\%) municipalities believe that customers and learning and growth perspectives are compromised because of IT outsourcing, while 7 (10.92\%) municipalities believe that IT outsourcing poses the biggest threat to the internal business process in the municipalities (Graph 5).

\section{Graph 5: Potential negative implications of IT outsourcing}

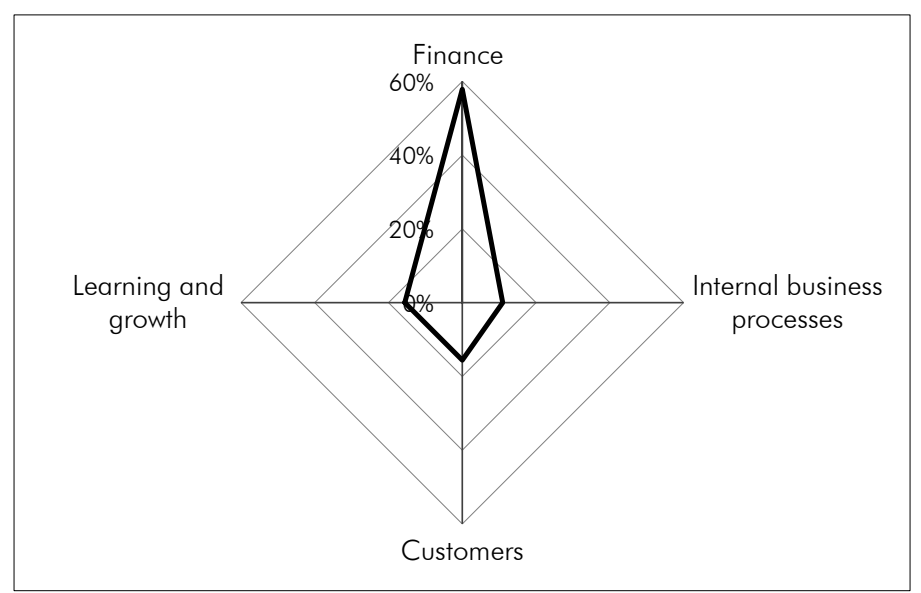

Regarding the daily operations of municipalities, the survey disclosed that 46 (72.00\%) municipalities do not have formal indicator models for measurement of organizational performance and efficiency. The survey also revealed that 60 (94.00\%) municipalities do not have comprehensive long-term strategy in the field of outsourcing (Graph 6). In addition, the research showed the vast majority of surveyed municipalities $(80.00 \%)$ have no actual evaluation framework, including objective criteria or a system of indicators to measure the eligibility of outsourcing decisions (Graph 6). 
Management of IT Outsourcing in the Slovenian Public Sector Material and Procedural Aspects

\section{Graph 6: Long term strategy and indicators for outsourcing}

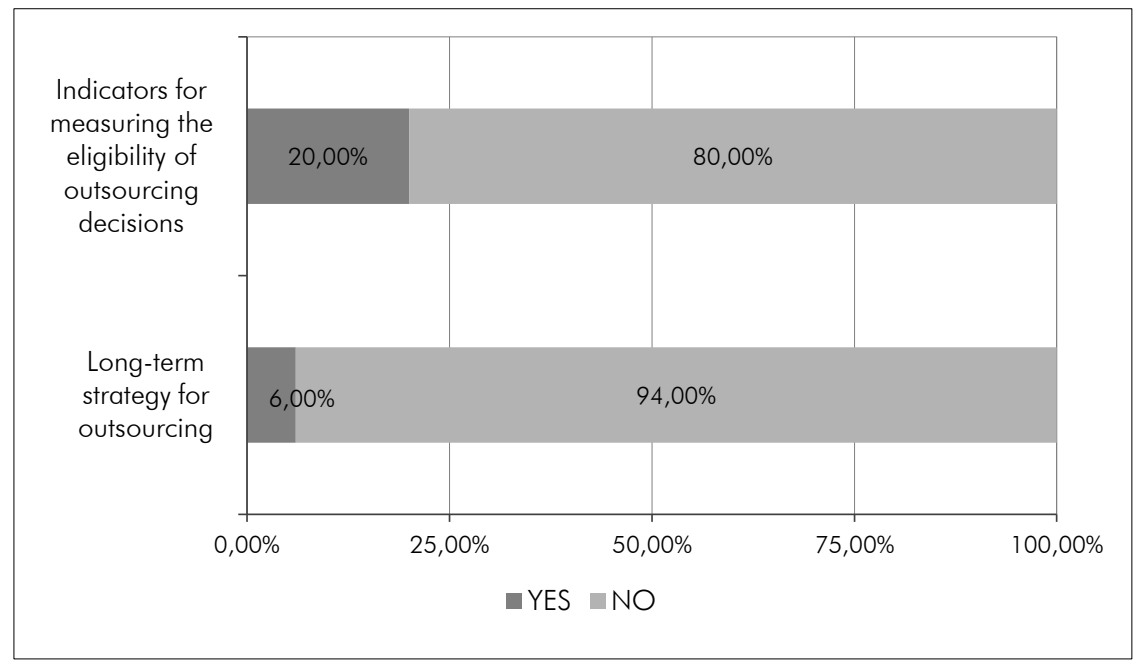

\section{Graph 7: Potential savings generated from in-house provision of IT-projects}

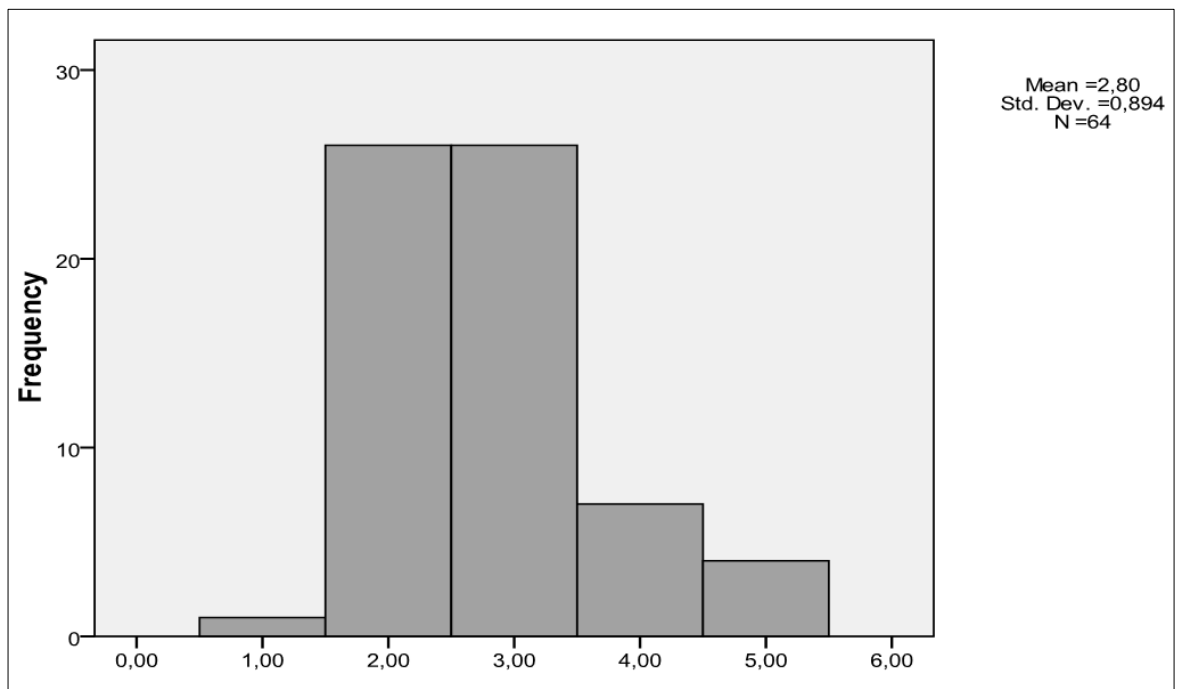

The surveyed municipalities have an average of 1.92 external suppliers in the field of IT, while their importance was assessed with an average rating of 4 on a scale of 1 to 5 , where 1 is unimportant and 5 is very important (2 fairly important, 3 medium-important, 4 important). Overall number of external suppliers, taking into account all areas of outsourcing, is averaging 5.98, amounting approximately to $17.76 \%$ of their annual 
budget, which accounts for a significant share. The largest percentage of the costs is allocated to IS, IT infrastructure and other areas related to IT summing up to $5.70 \%$, in second place is consulting and expertise with $4.61 \%$ share. Referring to the foregoing assessments, municipalities do not share very affirmative opinion on internal provision of IT-projects in general. In evaluating the savings that could be generated from in-house provision of IT-projects, municipalities' ratings were relatively low, namely on the scale from 1 to 5 ( 1 - insignificant and 5 - very high) mean value has reached 2.80 (std. error of mean 0.11 and std. deviation 0.89) (Graph 7).

Obtained results disclosed the need for better outsourcing strategy in the extensive and dynamic field of IT, indicating that municipal IT outsourcing initiatives are predominantly grounded in short-term financial benefits, while deeper reflections and rationales for outsourcing decisions are often omitted. Given the decrease of revenues and high indebtedness of municipalities in Slovenia, outsourcing issues necessitate a comprehensive understanding of this complex phenomenon, a consideration of all business and structural characteristics of municipalities, a strong management commitment in all phases of outsourcing process, a longterm risk assessment and restrained decisions following public benefits and an efficient public spending.

The section above presents only the survey results directly related to the main theme of the paper, while the overall presentation of research results and their detailed statistical analysis is not possible, due to the limited length of the paper. The next section presents a contextual framework for management of IT outsourcing based on material and procedural considerations highlighted in the survey and theoretical platform.

\section{Contextual framework for management of IT outsourcing}

Construction of a contextual framework for quality management of IT outsourcing in the public sector inevitably requires balancing several different factors, such as: economic, social, political, regulatory and technological. This requires the inclusion of numerous stakeholders with different priorities and objectives in all phases of IT outsourcing. Given the above arguments, the paper focuses on the classification and characterization of appropriate material and procedural factors and 
proposes the possible construction of contextual framework integrating the material and procedural aspect.

The presented contextual framework should provide a good basis for the development of objective and comprehensive management strategy which could assist decision makers in setting priorities and making enhanced decisions in the field of public sector outsourcing, as well as highlight some of the hidden aspects and potential problems that may arise in the process of IT outsourcing.

\subsection{Material aspect of IT outsourcing in the public sector}

In order for outsourcing to facilitate focus on core business, flexibility, cost effectiveness and meet other organizational needs, an outsourcing organization should assess the material importance of the outsourced activity or outsourced project in general (Cong \& Chau, 2010; Chen \& Bharadwai, 2009). While assessing different factors depending on the type of outsourcing project, its costs, risks, duration, goals and other important material implications, designated material factors relevant for the quality management of IT outsourcing may vary between different organizations (Ravindran et al., 2009; Goo et al., 2007). However, regardless of the organization, management should pay special attention to different material factors, as they follow (MAS, 2004):

- importance of the business activity to be outsourced, for example, in terms of contribution to income and profit;

- potential impact of the outsourcing on earnings, core competencies, human resources, organizational structure, user satisfaction, solvency, liquidity, funding and capital, and risk profile;

- impact on the institution's reputation and brand value, and ability to achieve its business objectives, strategy and plans, should the service provider fail to perform the service;

- cost of the outsourcing as a proportion of total operating costs of the institution;

- aggregate exposure to a particular service provider in cases where the institution outsources various functions to the same service provider;

- ability to maintain appropriate internal controls and meet regulatory requirements, if there were operational problems faced by the service provider. 
The material aspect contained by the contextual framework should define organizational priorities within the complex structure of the IT outsourcing process and incorporate complex interactions between material factors such as the degree of interdependence, and consider their long-term effects, especially their implication on organizational needs and goals. Determining material factors and effective use of the contextual framework therefore requires accuracy, consistency and detailed knowledge of both the organizational processes and outsourcing process, which consequently facilitates a balanced application of data for objective assessment of different material factors (Wang \& Yang, 2007; Humphreys et al., 2002). Material factors relevant for successful management of IT outsourcing projects are rarely studied in the wider context. The most prominent experts and researchers of outsourcing, its wider socio-economic implications and managerial aspects of outsourcing (Willcocks et al., 1999; Chapman \& Andrade, 1997; Jensen, 2007; Greaver, 1999; Bongard, 1994) emphasize the complexity of this phenomenon, which is reflected in the extremely multifaceted and complicated structure (Florin et al, 2005; Scholl, 2006; Walden \& Hoffman, 2007), while the long-term implications of outsourcing are often very well concealed, which makes them very difficult to manage.

Organizational factors, which represent the core material aspect in the process of IT outsourcing, should be defined in organizational policies, goals and objectives with strict regard to organization's strategic, tactical and operational considerations. Considering the numerous studies, potential long-term consequences as well as the complexity of the entire field of IT outsourcing and predominantly own research (Stanimirović, 2010; Vintar et al., 2010), where municipalities pointed out various outsourcing issues, based on the survey results we extracted the following material factors to be deployed in contextual framework for management of IT outsourcing:

1. Costs

2. Competencies

3. Quality

4. Customer satisfaction

5. Risk

6. Organization

7. Development

8. Innovation 
Management of IT outsourcing in the public sector is very specific as it covers very sensitive ground due to public financing and other eligible public interests, hence the relatively large number of material factors. Management of the public sector organizations should consider the effects of IT outsourcing on the listed material factors, while they represent the main material aspects of organization, concerning its financial stability, human resources, organizational structure and development. Public management must be therefore kept under constant alert, while harmonizing the implications of IT outsourcing with the complex nature of public sector and public benefits provision. Figure 1 illustrates the inclusion of these factors in a contextual framework, whereas the factors listed represent only the material aspect of a contextual framework, while the procedural aspect is presented in the section bellow.

Figure 1: Material aspect of managing IT outsourcing project

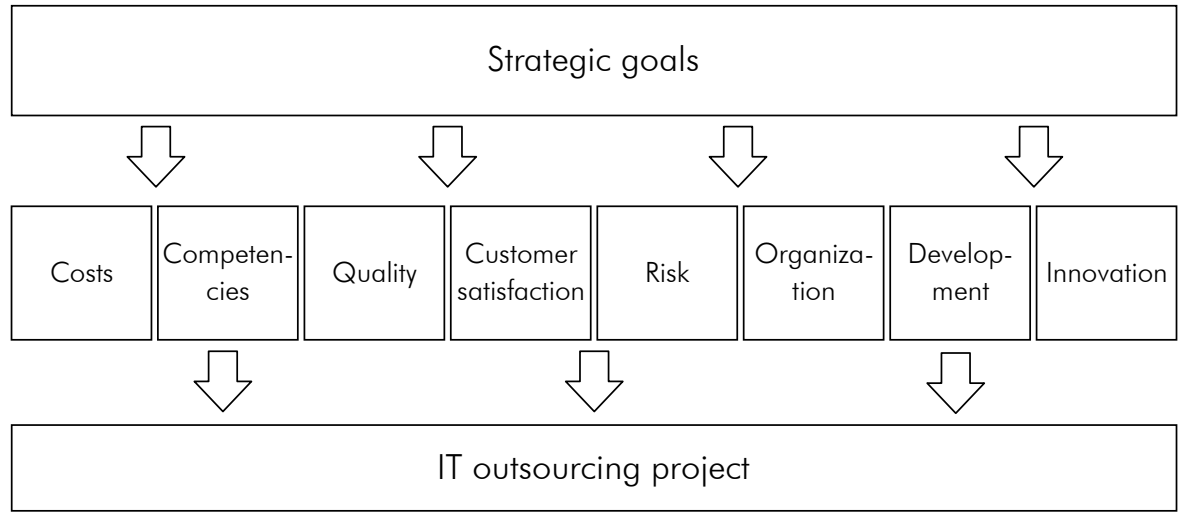

\subsection{Procedural aspect of IT outsourcing in the public sector}

Comprehensive contextual framework for quality management of IT outsourcing in the public sector requires integration of both material and formal aspects in order to facilitate a structured and quality decision making and governance of outsourcing projects. Factors listed represent the material aspect of IT outsourcing concerning its financial stability, service quality, human resources, risks, organizational structure and development, while the procedural aspect denotes the second integral part of contextual framework.

Procedural aspect in the process of IT outsourcing includes the consideration of legal framework, with strictly defined contractual 
relationship, transfer of liabilities, transfer of assets and statutory provisions in this area as well as contractual terms, such as: subject of the contract, obligations, Service Level Agreement (SLA), price, risk assessment, duration and termination, dispute resolution, choice of law and special provisions (Cong \& Chav, 2010; Goo et al., 2007; Ravindran et al., 2009). Well defined and detailed contract must provide a quality regulation of strategic elements within the outsourcing relationship, namely very clear definition of business requirements between both parties, comprehensive description of activities, outputs, performance as well as metrics and control mechanisms (Stanimirović, 2010; Chen \& Bharadwai, 2009). In addition to compliance with strict procedural regulations required by the legislation and contractual provisions, a significant part of the procedural aspect is an execution of market analysis, specifications of project requirements as well as preparation and execution of the public tender in order to select the best external supplier. The supplier selection phase should be followed by a phase of negotiation on terms of cooperation, transition of resources and finally once the outsourcing contract is already signed, management of IT outsourcing project should get underway providing supervision, timely anticipation of potential threats and various mechanisms to overcome those (Greaver, 1999; Wadhwa \& Ravindran, 2007; Walden \& Hoffman, 2007). Public management must be well informed and fully engaged in all phases of implementation process, while monitoring the impacts of IT outsourcing on public sector organizations and public service provision in general.

Based on procedural factors emphasized by the municipalities in our survey and theoretical platform described above, the procedural aspect of managing IT outsourcing process is structured and illustrated in Figure 2. If the whole process was well coordinated, management should be able to integrate material and procedural aspects and bring them in line with strategic objectives of the individual organization and the public sector in general. 
Figure 2: Procedural aspect of managing IT outsourcing project

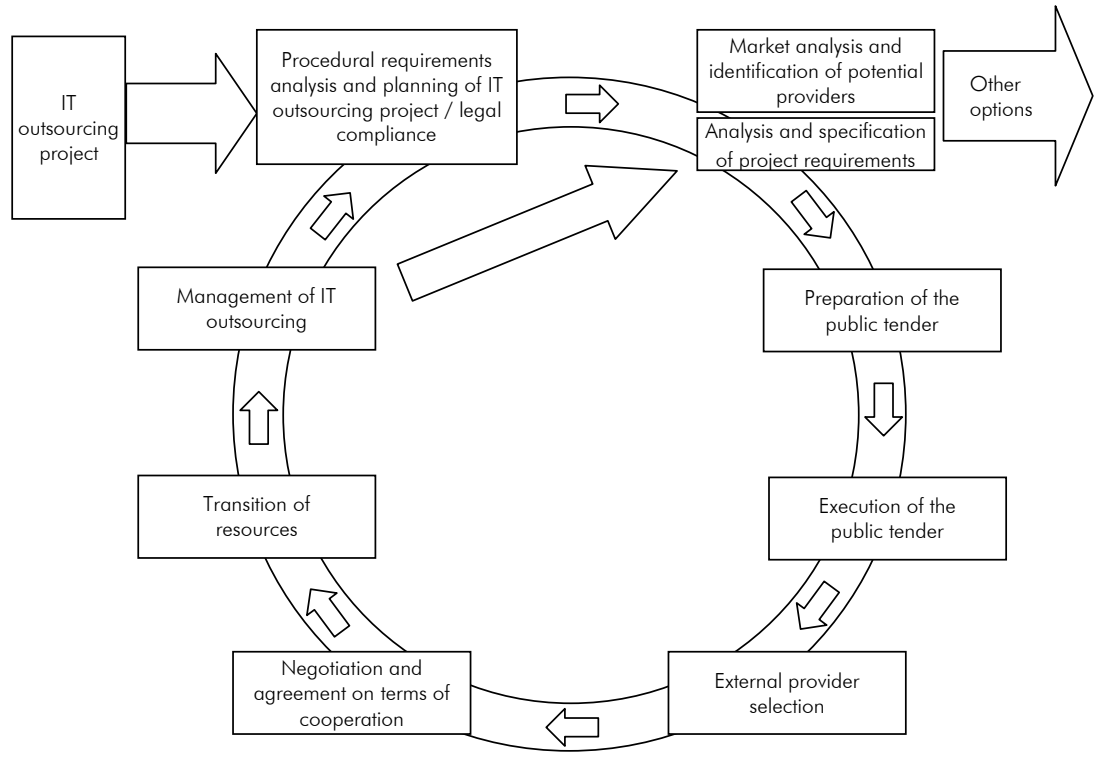

Only the integration of both material and procedural aspects in the comprehensive contextual framework can represent a useful platform for quality management and effective utilization of IT outsourcing strategies in public sector (Figure 3). The structure of the contextual framework allows necessary flexibility to the management of IT outsourcing projects, taking into account strategies, goals and objectives of the public sector organization. However, ensuring the appropriate quality level of the material and procedural factors throughout the IT outsourcing process remains a major problem. Presented contextual framework for quality management of IT outsourcing (Figure 3) is only one segment of the comprehensive methodology which was developed by the Institute for informatization of administration in cooperation with the Ministry of Public Administration and presents the groundwork in the research project (Stanimirović, 2010; Vintar at al., 2010) Evaluation of the effects of egovernment projects. 
Figure 3: Contextual framework for outsourcing of IT-projects in the public sector

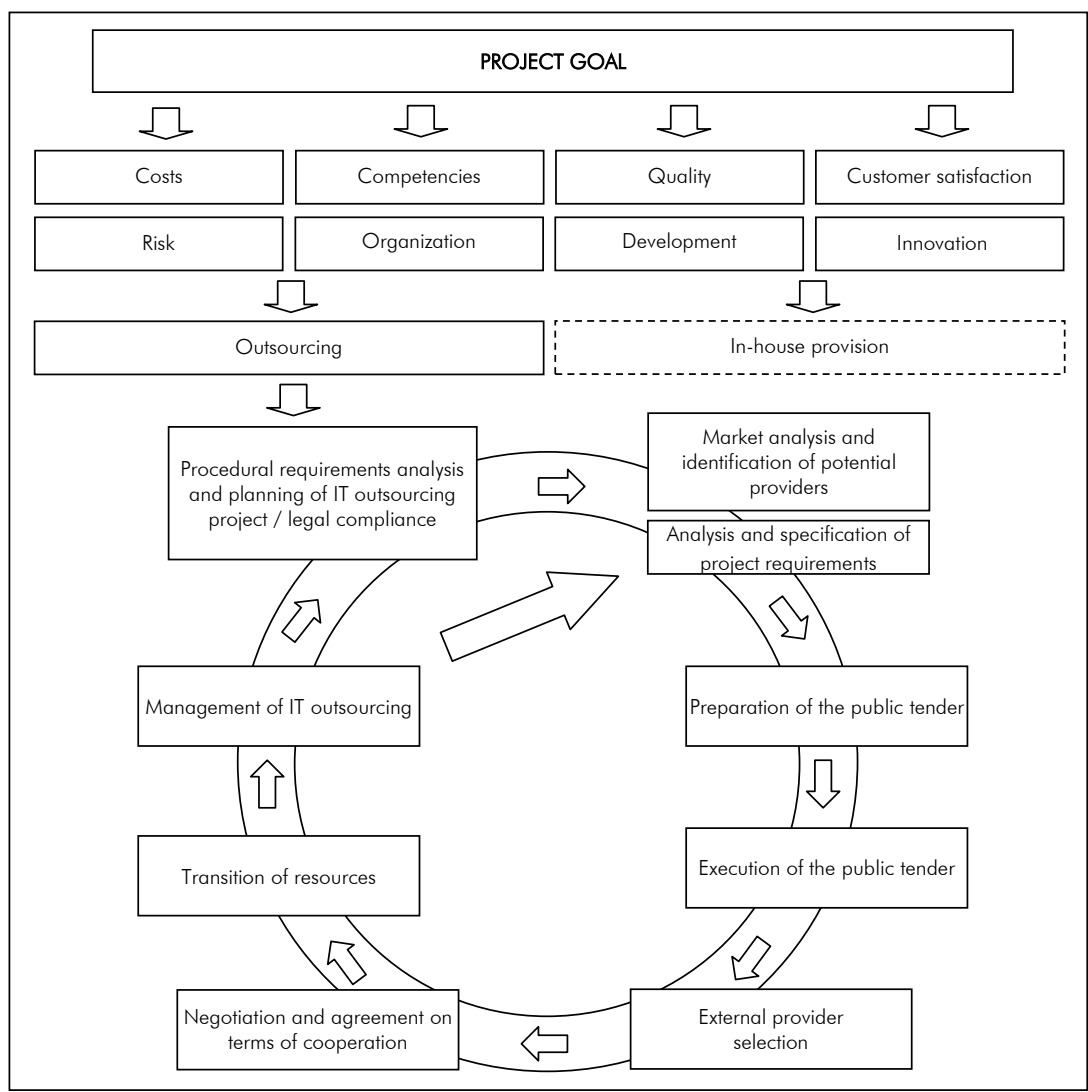

\subsection{Lessons learned and guidelines for effective utilization and implementation of IT outsourcing in the public sector}

If e-government, as some scholars believe, tends to progress towards vertical and horizontal integration at least within a given level and branch of government, sourcing decisions may require more frequent review and revision (Layne \& Lee, 2001 ; Scholl, 2006). In surveyed municipalities the following problem areas can be identified and highlighted:

- non-defined core and non-core activities in municipalities;

- the excessive and indiscriminate outsourcing and lack of strategy, as well as material and procedural standards in the field of outsourcing; 
- unawareness of the potential long-term negative implications of outsourcing projects;

- insufficient utilization of human and other resources and the synergies within the public sector organizations;

- lack of vision and strategic objectives of organizations within the public sector, exceeding a period of government mandate.

Unfortunately, research results cannot always be easily transferred into action, especially when the poor performance of the organization is related to several areas. Such situation requires a detailed analysis and preparation of solutions, which often necessitate a radical systemic change in the organization. A tighter integration of systems and application areas seems to call for the high internal availability of capabilities, competencies, and skills, and perhaps for increased insourcing of at least critical components and interfaces (Scholl, 2006). Bellow the guidelines will be presented that could bring improvement to the areas of particular concern and risk, which were disclosed by the survey results:

- definition of core and non-core activities in the functioning of municipalities;

- formulation of outsourcing strategy, creation of formal approach including strict compliance with material and procedural requirements and development of indicator models needed for evidence-based management through the whole cycle of outsourcing process;

- assessment of the potential long-term negative implications of outsourcing projects;

- utilization of human and other resources as well as hidden potential and synergy within numerous public sector organizations;

- formulating a vision, strategic objectives, and precise tactics as well as providing funds for achieving long-term organizational goals, beyond a period of government mandate.

\section{Conclusion}

The featured research issues illustrated the problems and challenges faced by public sector organizations in their efforts to keep pace with dynamic socio-economic and technological environment. The obtained results of 
the survey indicate only a partial, but a valuable insight into the outsourcing of IT projects in Slovenian municipalities. Specific modus operandi and characteristic role of municipalities in the administrative system preclude generalization and prevent application of the obtained results to all public sector organizations in Slovenia, but nevertheless they can provide a good overall impression of the particular problems associated with IT outsourcing in the public sector.

The scale of the studied area and numerous factors affecting the management and implementation of IT outsourcing projects confirm the multiplicity and complexity of outsourcing and its long-term implications in many areas of organizational activity. The latter substantiates the need for a broader and deeper insight into the background and content of overall business strategy of Slovenian municipalities and public sector in general. The search of primarily short-term solutions and inadequate business strategy as well as uncritical managerial approaches in recent years have brought public sector organizations in a very complex situation, so it is high time for more serious reflection on management role in the future, and mechanisms that will have to ensure selection of appropriate business strategies, effective spending of budget funds and successful achievement of long-term goals. Even more, regarding the context and degree of given problems, the objective and critical approach to the management of IT outsourcing should receive greater support from all stakeholders and become a necessity.

The critical analysis of the IT outsourcing concept presented in the paper involved a revision of its long-term implications as well as assessment of material and procedural aspects of IT outsourcing and their integration in the comprehensive contextual framework which could offer a valuable support to the managerial decision making processes concerning the implementation of IT outsourcing projects. Clearly, the contextual framework comprising material and procedural requirements does not represent the universal solution to important problems addressed in this paper in a self-sufficient form. However it may offer, due to its simplicity of use and definition of appropriate material and procedural requirements, a lot of help to the management in all phases of IT outsourcing process. It can also provide assistance in allocation of project management resources as well as facilitate evidence-based decision making and reduce risk in implementation of IT outsourcing projects. Despite some shortcomings, which can be seen mainly in the objective limitations of 
political, regulatory and organizational nature within the public sector, such formal approaches should become a standard in the operating and managerial procedures in the public sector. Application of contextual framework for outsourcing of IT projects, which is still undergoing the evaluation process in the field of Slovenian e-government, despite required upgrading and adaptation to the specific area of use, could become a useful tool for public sector management. The current practice concerning management of IT outsourcing is based on inertia, intuitive decisions and primarily on the fabrication of studies evaluating IT outsourcing projects much unilaterally and without regard to their longterm and versatile consequences affecting all public sector stakeholders.

Dalibor Stanimirović is a researcher in the field of Informatics in public administration. Throughout his work he has been involved in various research projects concerning this field of expertise, while his research work on IT enabling reform and development of public administration has been published in several national and international journals. His general research interests include IT in public administration, government Enterprise Architecture, e-government, health care information systems and social dimensions of IT.

Prof. dr. Mirko Vintar is professor of Information systems in Public Administration and E-government. For over 20 years his work has dealt with the informatisation of public administration, with a major focus on the development of e-government in recent years. He has managed a number of national and international research and development projects in this field. A member of numerous national and international scientific and professional committees and working groups involved in the research (EGPA, Study Group on Informatisation of Public Administration, IFIP WG 8.5, NISPAcee - WG on E-government). From 1993 to 2002 he was the chief editor of the Journa/ Uporabna informatika (Applied Informatics). 


\section{References}

- Barney, J. (1991). Firm Resources and Sustained Competitive Advantage. Journal of Management 17(1), 99-120.

- Bongard, S. (1994). Outsourcing - Entscheidungen in der Informationsverarbeitung. Entwicklung eines computergestützten PortfolioInstrumentariums, pp. 480. Wiesbaden: Deutscher Universität Verlag.

- Boyne, G. A. (1998). Bureaucratic Theory Meets Reality: Public Choice and Service Contracting in U.S. Local Government. Public Administration Review 58(6), 474-484.

- Chapman, R. B., \& Andrade, K. R. (1997). Insourcing after the Outsourcing: MIS Survival Guide. AMACOM.

- Chen, Y. \& Bharadwaj, A. (2009). An Empirical Analysis of Contract Structures in IT Outsourcing. Information Systems Research 20(4), 484-506.

- Choy, K. L., Lee, W. B., Lau, H. C. W. \& Choy, L. C. (2005). A KnowledgeBased Supplier Intelligence Retrieval System for Outsource Manufacturing. Knowledge-Based Systems 18(1), 1-17.

- Cong, Q., \& Chau, P. Y. K. (2010). Relationship and Contract Issues of IT Outsourcing - Descriptive Case Studies in China Regions. PACIS 2010 Proceedings. Paper 15.

- Corbett, M. F. (2004). The Outsourcing Revolution: Why It Makes Sense and How to Do It Right. Washington: Kaplan Business.

- Cordella, A., \& Willcocks, L. P. (2010). Outsourcing, Bureaucracy and Public Value: Reappraising the Notion of the "Contract State". Government information quarterly 27(1), 82-88.

- Due, R. T. (1992). The Real Costs of Outsourcing. Information Systems Management 9(1), 78-81.

- Ellram, L. M. \& Maltz, A. (1997). Outsourcing: Implications for Supply Management. Tempe, AZ: CAPS Research.

- Florin, J., Bradford, M. \& Pagach, D. (2005). Information Technology Outsourcing and Organizational Restructuring: An Explanation of their Effects on Firm Value. Journal of High Technology Management Research 16(2), 241-253.

- Ford, D. \& Farmer, D. (1986). Make or Buy: A Key Strategic Issue. Long Range planning 19(5), 54-62.

- Ghodeswar, B. \& Vaidyanathan, J. (2008). Business Process Outsourcing: An Approach to Gain Access to World-Class Capabilities. Business Process Management Journa/ 14(1), 23-38.

- Goo, J., Kishore, R., Nam, K., Rao, H. R. \& Song, Y. (2007). An Investigation of Factors that Influence the Duration of IT Outsourcing Relationships. Decision Support Systems 42(4), 2107-2125.

- Greaver, M. F. (1999). Strategic Outsourcing: A Structured Approach to Outsourcing Decisions and Initiatives. AMACOM. 
- Hirschheim, R. \& Lacity, M. (2000). The myths and realities of information technology insourcing. Communications of the ACM 43(2), 99-107.

- Hodgson, L., Farrell, C., \& Connolly, M. (2007). Improving UK Public Services: A Review of the Evidence. Public Administration 85(2), 355-382.

- Ho, L. \& Atkins, A. S. (2010). IT Outsourcing: Impacts and Challenges. In K. St. Amant (Ed.). IT Outsourcing: Concepts, Methodologies, Tools and Applications (29-49). New York: Business Science Reference.

- Hood, C. G. \& Peters, G. (2004). The Middle Aging of New Public Management: Into the Age of Paradox. Journal of Public Administration Research and Theory 14(3), 267-282.

- Humphreys, P., Mclvor, R. \& Huang, G. (2002). An Expert System for Evaluating the Make or Buy Decision. Computers \& Industrial Engineering 42(2-4), 567-585.

- Jacobides, M. G. (2005). Industry Change through Vertical Disintegration: How and Why Markets Emerged in Mortgage Banking. Academy of Management Journal 48(3), 465-498.

- Jensen, P. H. (2007). Public Sector Outsourcing Contracts - The Impact of Uncertainty, Incentives and Transaction Costs on Contractual Relationships. Saarbrücken: VDM Verlag, Dr. Mueller e. K.

- Johnson, M. (1997). Outsourcing in Brief. Oxford: Butterworth-Heinemann.

- Kakabadse, A. \& Kakabadse, N. (2001). Outsourcing in the Public Services: A Comparative Analysis of Practice, Capability and Impact. Public Administration and Development 21 (5), 401-413.

- Kakabadse, A. \& Kakabadse, N. (2003). Outsourcing Best Practice: Transformational and Transactional Considerations. Knowledge and Process Management 10(1), 60-71.

- Kavčič, K. \& Tavčar, M. I. (2008). Interesi in razmerja moči med udeleženci outsourcinga: študija primerov. Organizacija 41 (1), 2-16.

- Kern, T., Willcocks, L. P. \& van Heck, E. (2002). The Winner's Curse in IT Outsourcing: Strategies for Avoiding Relational Trauma. California Management Review 44(2), 47-69.

- Kim, B. (2003). Dynamic Outsourcing to Contract Manufacturers with Different Capabilities of Reducing the Supply Cost. Int. J. Production Economics 86(1), 63-80.

- Kim, H. J., Pan, G. \& Pan, S. L. (2007). Managing IT-Enabled Transformation in the Public Sector: A Case Study on E-Government in South Korea. Government Information Quarterly 24(2), 338-352.

- Kubr, M. (2002). Management Consulting: A Guide to the Profession. Geneva: International Labour Organization.

- Lacity, M. C., Khan, S., Yan, A. \& Willcocks, L. P. (2010). A Review of the IT Outsourcing Empirical Literature and Future Research Directions. Journal of Information Technology 25(4), 395-433.

- Lapsley, I. (2009). New Public Management: Cruellest Invention of the Human Spirit? Abacus 45(1), 1-21. 
- Layne, K. \& Lee, J. (2001). Developing Fully Functional E-Government: A Four-Stage Model. Government Information Quarterly 18(2), 122-136.

- Lee, Y. H., Jeong, C. S. \& Moon, C. (2002). Advanced Planning and Scheduling with Outsourcing in Manufacturing Supply Chain. Computers \& Industrial Engineering 43(1-2), 351-374.

- Linder, J. C. (2004). Outsourcing for Radical Change: A Bold Approach to Enterprise Transformation, 1st Edition. New York: AMACOM.

- Lonsdale, C. \& Cox, A. (1997). Outsourcing: Risk and Rewards. Supply Management 2(14), 32-34.

- Martin, S. (2010). From New Public Management to Networked Community Governance? Strategic Local Public Service Networks in England. In S. Osborne (Ed.). The New Public Governance? Emerging Perspectives on the Theory and Practice of Public Governance (337-348). London: Routledge.

- MAS. Monetary Authority of Singapore. (2004). Guidelines on Outsourcing. Republic of Singapore.

- Nellore, R. \& Soderquist, K. (2000). Strategic Outsourcing through Specifications. Omega - The International Journal of Management Science 28(5), 525-40.

- Pandey, V. \& Bansal, V. (2003). A Decision-Making Framework for IT Outsourcing using the Analytic Hierarchy Process. Journal of Academy of Business and Economics, South Stockholm University, Sweden.

- Peteraf, M. A. (1993). The Cornestones of Competitive Advantage: A Resource-Based View. Strategic Management Journal 14(3), 179-191.

- Power, M. J., Desouza, K. \& Bonifazi, C. (2006). The Outsourcing Handbook: How to Implement a Successful Outsourcing Process. Chicago: Kogan Page.

- Quinn, J. B. \& Hilmer, F. G. (1994). Strategic Outsourcing. Sloan Management Review 35(4), 43-55.

- Ravindran, K., Susarla, A., Gurbaxani, V. (2009). Social Network and Contract Enforcement in IT Outsourcing. In: Proceedings of the 30th International Conference on Information Systems, Phoenix, paper 143.

- Rocheleau, B. \& Wu, L. (2002). Public versus Private Information Systems: Do They Differ in Important Ways? A Review and Empirical Test. American Review of Public Administration 32(4), 379-397.

- Scholl, H. J. (2006). Electronic Government: Information Management Capacity, Organizational Capabilities, and the Sourcing Mix. Government Information Quarterly 23(1), 73-96.

- Schniederjans, M. J., Schniederjans, A. M. \& Schniederians, D. G. (2005). Outsourcing and Insourcing in an International Context. London: M. E. Sharpe.

- Stanimirović, D. (2010). Decision Making Criteria for Outsourcing or Insourcing of IT Service Provision in the Public Sector. Ljubliana: University of Liubliana, Institute for Informatization of Administration.

- Taylor, H. (2006). Critical Risks in Outsourced IT Projects: The Intractable and the Unforeseen. Communications of the ACM 49(11), 75-79. 
- Vintar, M., Jukić, T. \& Stanimirović, D. (2010). Evaluation of the effects of e-government projects. Research report. Ljubljana: University of Ljubljana, Institute for Informatization of Administration; Ministry of Public Administration.

- Wadhwa, V. \& Ravindran, A. R. (2007). Vendor Selection in Outsourcing. Computers \& Operations Research 34(12), 3725-3737.

- Walden, E. A. \& Hoffman, J. J. (2007). Organizational Form, Incentives and the Management of Information Technology: Opening the Black Box of Outsourcing. Computers \& Operations Research; 34(12), 3575-3591.

- Wang, J. J. \& Yang, D. L. (2007). Using a Hybrid Multi-Criteria Decision Aid Method for Information Systems Outsourcing. Computers \& Operations Research 34(12), 3691-3700.

- Willcocks, L. P. \& Lacity, M. C. (1995). Information Systems Outsourcing in Theory and Practice. Journal of Information Technology 10(4), 203-207.

- Willcocks, L. P., Fitzgerald, G. \& Lacity, M. C. (1999). To Outsource IT or Not? Research on Economics and Evaluation Practice. In: Wilcocks, L. P. \& Lester, L. (Eds.). Beyond the IT Productivity Paradox (293-333). Chichester: Wiley. 
POVZETEK

\section{MENEDŽMENT ZUNANJEGA IZVAJANJA IT-PROJEKTOV V SLOVENSKEM JAVNEM SEKTORJU - VSEBINSKI IN POSTOPKOVNI VIDIKI}

Ključne besede: javni sektor, občina, zunanje izvajanje IT-projektov, proces zunanjega izvajanja IT-projektov, vsebinski in postopkovni vidiki zunanjega izvajanja IT-projektov

Spremenjene ekonomske razmere $v$ pogojih globalne konkurence so $v$ zadnjih treh desetletiih sprožile potrebe po reformah tako $\vee$ zasebnem kot $v$ javnem sektorju. Družbenoekonomski razvoi je s svojim pritiskom na javne finance sprožil številna vprašanja o učinkovitem, preglednem in namenskem trošenju proračunskih sredstev. Sočasen razvoj ekonomskih in upravnih znanosti ter tehnologije je $v$ osemdesetih letih prejšnjega stoletja privedel do oblikovanja in vpeljave novih poslovnih strategij v javni sektor, ki je zaradi vse boli perečih finančnih težav začel uporabljati nekatere poslovne strategije, ki so bile do tedaj prisotne le $v$ zasebnem sektorju. Niihova uporaba naj bi predvsem znižala stroške poslovanja ter povečala uspešnost in učinkovitost javnih organizacij. Strategija, imenovana zunanje izvajanje storitev oziroma outsourcing (okrajšava iz angleške fraze: outside source using), je tako postala orodje javnega menedžmenta, ki je pričel po vzgledu zasebnih podjetij z intenzivnim oddajanjem del zasebnim ponudnikom, ki so na podlagi sklenjene pogodbe z organizacijami iz javnega sektorja opravljali storitve na najrazličnejših področjih javnega značaja.

Splošno je torej zunanje izvajanje storitev mogoče razumeti kot strategijo poslovanja, pri kateri organizacija iz določenih razlogov (največkrat so to stroškovni razlogi) odda zunanjim izvajalcem opravljanje določenih delovnih procesov oziroma določenih storitev, z namenom osredotočanja na svoje ključne naloge in temeljne dejavnosti. Organizacija se lahko tako $v$ določeni meri izogne naložbam $v$ materialna sredstva, spremeni fiksne stroške $v$ variabilne ter izboljša stroškovno učinkovitost, omogoči poslovno prestrukturiranje in rast, visoko usposobljene kadre in strokovne sodelavce pa preusmeri na ključne dejavnosti oziroma naloge, od katerih si obeta dolgoročno uspešnost in učinkovitost. To so očitne prednosti 
zunanjega izvajanja, vendar je treba temeljito preučiti, kaj lahko kratkoročna učinkovitost pomeni za dolgoročno uspešnost organizacii, še posebej tistih $v$ javnem sektorju. Poleg prednosti in koristi se je namreč treba zavedati dejstva, da projekti zunanjega izvajanja storitev nosijo potencialno $v$ sebi tudi številne slabosti in tveganja, ki jih je nujno treba objektivno ovrednotiti in analizirati pred sprejemom odločitve za vzpostavitev tovrstnih projektov. Najbolj problematično pri projektih zunanjega izvajanja storitev je dejstvo, da se težave pričnejo pojavljati s časovno zamudo, ko je organizacija že globoko vpeta $v$ projekt. Za nastalo situacijo je mogoče najti več različnih vzrokov pri obeh sodelujočih poslovnih subjektih. Številni strokovnjaki poudarjajo, da so podjetja $\vee$ zasebnem sektorju najboli ogrožena zaradi izbire napačnega zunanjega izvajalca, organizacije $v$ javnem sektorju pa zaradi zunanjega izvajanja neustreznih dejavnosti, nepredvidenih stroškov in dolgoročne izgube ključnih kompetenc znotraj organizacije. Zunanje izvajanje storitev $\checkmark$ javnem sektorju je bilo v zadnjih dveh desetletjih tarča ostrih polemik. Na eni strani je jasno, da nemoteno delovanje javnega sektorja zahteva sodelovanje z zasebnimi podjetji, pojavlja pa se vprašanje, katere dejavnosti so primerne za zunanje izvajanje in $v$ kolikšni meri, na drugi strani pa raziskave že od konca devetdesetih let prejšnjega stoletja razkrivajo nezadovoljstvo javnih organizacii z dolgoročno učinkovitostjo zunanjega izvajanja in s slabimi rezultati projektov zunanjega izvajanja. Javne organizacije so se skoraj enoglasno pritoževale zaradi nepredvidene rasti stroškov, izgube nadzora nad delovnimi procesi in človeškimi viri ter slabšanja kakovosti storitev zunanjih izvajalcev. Odsotnost dovolj kritičnega pristopa pri opredeljevanju realnih potreb in odločanju za zunanje izvajanje storitev je javne organizacije večkrat pripeljala $v$ zelo težke položaje, včasih tudi do roba samega obstoja. Organizacije so zaradi kratkoročnih koristi ogrozile svoj dolgoročni razvoi ter onemogočile doseganje strateških ciljev celotnega javnega sektorja. Izkušnje, ki so se trideset let nabirale na področju zunanjega izvajanja storitev, so v zadnjih letih presegle kritično maso, tako da lahko danes pravzaprav govorimo o obratnem trendu $v$ javnem sektorju, torej vrnitvi $k$ notranjemu izvajanju storitev in poslovnih procesov (insourcing). $V$ Sloveniji je kljub dvomom mnogih strokovnjakov o upravičenosti tega početja $v$ zadnjih desetih letih opazna skokovita rast javnih razpisov $z$ namenom sklepanja pogodb za zunanje izvajanje IT-projektov. Po ocenah nekaterih strokovnjakov se je višina stroškov za projekte zunanjega izvajanja $\vee$ slovenskem javnem sektorju $\vee$ zadnjih letih podvojila in $v$ času 
aktualne gospodarske in finančne krize dosega po grobih ocenah več deset milijonov evrov.

$\checkmark$ luči predstavljene problematike prispevek preučuje doslej še relativno neraziskano področje slovenskega javnega sektorja. Osredotoča se namreč na predstavitev koncepta zunanjega izvajanja, poglobljeno analizo pro et contra argumentov in predstavlja raziskovalne izsledke glede zunanjega izvajanja IT-projektov $v$ slovenskih občinah ter predstavlja konceptualni model za menedžment zunanjega izvajanja IT-projektov $v$ slovenskem javnem sektorju. Predmet raziskovanja je interdisciplinarno področje zunanjega izvajanja IT-projektov v javnem sektorju oziroma njegovo presečišče z različnimi ekonomskimi, upravnimi, informacijskimi in drugimi znanstvenimi paradigmami. Sama širina predmeta raziskovanja kaže, da parcialni pristopi, ki temeliijo zgoli na ekonomskih predpostavkah, ne morejo ponuditi celovitega in dolgoročno vzdržnega modela za implementacijo in menedžment zunanjega izvajanja IT-projektov v javnem sektorju. Metodološki okvir raziskave je prilagojen kompleksnosti raziskovalne problematike. Prispevek se $v$ teoretičnem delu opira na spoznanja o zunanjem izvajanju, ki so jih objavili domači in tuji avtorji. Pri tem so uporabljene že uveljavljene metode kvalitativnega raziskovanja. Teoretičnemu delu sledi empirični del, ki temelji na empirični raziskavi, ki je bila izvedena $v$ slovenskih občinah. Ta je bila opravljena z vprašalnikom, pogovori in pregledom projektne dokumentacije. Z uporabljenimi metodami kvalitativnega raziskovanja in ustreznimi statističnimi orodii so bila povezana teoretična in praktična spoznanja o zunanjem izvajanju IT-projektov ter podani konceptualni model in smernice za učinkovito implementacijo strategije zunanjega izvajanja IT-projektov v slovenskem javnem sektorju. Prispevek v uvodnem delu predstavlja paradigmo "Novega javnega menedžmenta" in koncept zunanjega izvajanja ter ekonomska, upravna in druga izhodišča, ki so pripeljala do njegove vpeljave. $\vee$ nadaljevanju tudi navaja potencialne pozitivne in negativne implikacije zunanjega izvajanja IT-projektov in podaja oceno trenutnega stanja na področju zunanjega izvajanja IT-projektov $v$ slovenskem javnem sektorju. Znana literatura namreč ne osvetljuje kompleksne in multidimenzionalne strategije zunanjega izvajanja IT-projektov s širšega vidika, ampak se največkrat osredotoča predvsem na zelo ozek vidik stroškov in drugih, predvsem finančnih koristi, kar pa ne daje dovoli celovitih odgovorov glede prednosti in slabosti strategije zunanjega izvajanja storitev. Slednje je še posebej pomembno 
v povezavi z javnim sektorjem, čigar primarna funkcija je vsekakor nudenje javnih storitev in zadovoljevanje širših družbenih potreb, ki jih ni mogoče preprosto zreducirati in prenesti na zunanjega (zasebnega) izvajalca zaradi znižanja stroškov. $\vee$ osrednjem delu prispevka so predstavljene raziskava zunanjega izvajanja IT-projektov $v$ slovenskih občinah in glavne značilnosti tovrstnih projektov na občinski ravni, razkriti pa so tudi pogledi občin in razmišljanja povezana z zunanjim izvajanjem IT-projektov ter glavni razlogi za izbiro strategije zunanjega izvajanja.

Doseženi rezultati raziskave so ponudili sicer samo parcialen, vendar dragocen vpogled $v$ področje zunanjega izvajanja IT-projektov $v$ slovenskih občinah. Anketni vzorec je zajemal 85 občin, od 211 občin v Sloveniji, od tega se je na anketo odzvalo 64 občin. Relativna majhnost vzorca sicer onemogoča posploševanje trditev in uporabo rezultatov raziskave na ravni celotnega javnega sektorja, vendar je kljub temu dober kazalnik nekaterih težav, s katerimi se srečujejo posamezne javne organizacije in posledično tudi celoten javni sektor. Rezultati raziskave so pokazali, da je $v$ anketiranih občinah mogoče identificirati in poudariti predvsem naslednja problematična področja: čezmerno in nekritično oddajanje del zunanjim izvajalcem in pomanjkanje strategije na področju zunanjega izvajanja IT-projektov (pomanjkanje objektivnih in merljivih kriterijev ter kazalnikov, na katerih temeliijo odločitve za zunanje izvajanje, odločanje za zunanje izvajanje predvsem zaradi predvidenega zniževanja stroškov in zanemarjanje drugih organizacijskih vidikov, predvsem razvojnega in kadrovskega), nerazumevanje potencialnih dolgoročnih negativnih posledic projektov zunanjega izvajanja (prikriti in nepredvideni stroški, odvisnost od zunanjih izvajalcev, nepregledni javni razpisi, slabo definirane pogodbe z zunanjimi izvajalci, prevelika povezanost organizacii javnega sektorja z zunanjimi izvajalci) in neizkoriščenost kadrovskih in drugih potencialov ter sinergije znotraj lastnih vrst $v$ organizacijah javnega sektorja. Rezultati raziskave nakazujejo, da je prav izbira ustrezne strategije poslovanja tisto, kar lahko deluje kot katalizator pri ustvarjanju večje učinkovitosti in racionalnosti pri doseganju ciljev javnega sektorja. Na podlagi raziskovalnih izsledkov in analize rezultatov so $v$ zaključnem delu prispevka opredeljeni vsebinski, postopkovni in drugi pomembni vidiki v procesu zunanjega izvajanja IT-projektov, ki so pomembni za učinkovito načrtovanje in implementacijo zunanjega izvajanja IT-projektov $\checkmark$ javnem sektorju. Vsebinski in postopkovni vidik zunanjega izvajanja IT-projektov sta $v$ nadaljevanju predstavljena znotraj lastnih modelov, 
ki podrobno predstavljata vsebinske elemente in postopkovne faze znotrai določenega vidika. Tako vsebinski kot tudi postopkovni vidik sta nato integrirana $v$ celovit konceptualni model, ki naj bi omogočal kakovosten menedžment zunanjega izvajanja IT-projektov $v$ javnem sektorju. Ob koncu prisperka so podane tudi smernice in predlogi za učinkovito implementacijo strategije zunanjega izvajanja IT-projektov $v$ slovenskem javnem sektorju.

Prispevek predstavlja stanje na področju zunanjega izvajanja IT-projektov $v$ slovenskih občinah ter osvetljuje skrite vidike in potencialne dolgoročne implikacije projektov zunanjega izvajanja na različne organizacijske dejavnike $\vee$ javnem sektorju. Raziskava potrjuje specifičnost zunanjega izvajanja $v$ javnem sektorju in potrebo po boli poglobljeni analizi in kritičnem razmisleku v fazi odločanja za tovrstne strategije. Odločanje na področju zunanjega izvajanja IT-projektov v javnem sektoriu ne bi smelo temeljiti na pavšalnih ocenah in pogosto arbitrarnih odločitvah, ampak na empiričnih dognanjih in domišljenih modelih za podporo odločanju, ki bi zagotavljali celovito predhodno evalvacijo projektov zunanjega izvajanja, predstavitev različnih kvantitativno ovrednotenih alternativ in na objektivnih podatkih temelječe smernice za podporo odločanju tako $v$ fazi načrtovanja kot tudi implementacije zunanjega izvajanja IT-projektov $v$ javnem sektorju. Predstavljeni konceptualni model, ki vključuje tako vsebinski kot postopkovni vidik, lahko ponudi dobro osnovo za celoviti menedžment zunanjega izvajanja IT-projektov. Kljub določenim slabostim, ki so lahko vidne predvsem pri nedoslednem upoštevanju vsebinskih in postopkovnih dejavnikov, ter objektivnim omejitvam politične, normativne in organizacijske narave znotraj javnega sektorja, bi lahko tovrstni modeli za podporo odločanju postali standard pri sprejemanju odločitev za zunanje izvajanje IT-projektov $v$ javnem sektorju. Potencialna nadgradnja modelov za podporo odločanju in njihova prilagoditev glede na specifičnost posamezne organizacije znotrai javnega sektorja, pa bi omogočali tudi prenos na druga področja. Dosedanja praksa $v$ procesih odločanja za zunanje izvajanje $v$ javnem sektorju je največkrat temeljila na enostranskih, predvsem stroškovnih ocenah, brez upoštevanja kompleksnih in dolgoročnih vplivov strategije zunanjega izvajanja na vse deležnike znotraj javnega sektoria. 